\title{
AS PRÁTICAS ORGANIZATIVAS DO DISTRITO DE RATONES NA RESISTÊNCIA À PROPOSTA DE PLANO DIRETOR “PARTICIPATIVO" FEITA PELA PREFEITURA DE FLORIANÓPOLIS, À LUZ DA TEORIA POLÍTICA DO DISCURSO
}

1- Kellen da Silva Coelho*

Doutora em Administração pela Universidade Federal de Santa Catarina (UFSC), Brasil.

Professora do Departamento de Administração da Universidade Federal da Paraíba (UFPB), Brasil. kellen.coelho@hotmail.com

http://lattes.cnpq.br/3964745371675593

2- Eloise Helena Livramento Dellagnelo

Doutorado em Engenharia de Produção pela Universidade Federal de Santa Catarina (UFSC), Brasil. Professora do Programa de Pós-Graduação em Administração da Universidade Federal de Santa Catarina (UFSC), Brasil. eloise@cse.ufsc.br

http://lattes.cnpq.br/3244169701712582

\section{3- Amarildo Felipe Kanitz}

Doutor em Geografia pela Universidade Federal de Santa Catarina (UFSC), Brasil. amarildofelipekanitz@gmail.com http://lattes.cnpq.br/1577578770727464 


\title{
AS PRÁTICAS ORGANIZATIVAS DO DISTRITO DE RATONES NA RESISTÊNCIA À PROPOSTA DE PLANO DIRETOR “PARTICIPATIVO" FEITA PELA PREFEITURA DE FLORIANÓPOLIS, À LUZ DA TEORIA POLÍTICA DO DISCURSO ${ }^{1}$
}

\section{Resumo}

Ao entender que, na contra hegemonia, pudesse se manifestar um organizar alternativo, analisaram-se práticas organizativas do movimento de resistência à proposta de Plano Diretor "Participativo" da Prefeitura Municipal de Florianópolis, entre 2009 e 2011, em especial as práticas do Distrito de Ratones. Este movimento compunhase de pessoas de diversos segmentos da sociedade, dentre eles membros dos treze distritos do Município. Inicialmente, tendia-se a crer que, em distritos onde houvesse uma tradição de luta por participação política, a organização da resistência ao modelo dominante de planejar o município se configurasse de modo mais efetivo. Contudo, o Distrito de Ratones, sem essa tradição de luta política na história do Planejamento Urbano de Florianópolis, também manifestou uma organização da resistência efetiva e, por esta singularidade, foi possível supor que tal organização apresentasse indícios de práticas organizativas alternativas ao modelo dominante de organizar e assim, tornou-se objeto de análise deste artigo. Na tentativa de não se vitimar pela concepção dominante de estudos organizacionais e pela noção, muitas vezes, restrita de organização nos estudos sobre movimentos sociais, utilizou-se a Teoria Política do Discurso. Os resultados revelaram que o distrito, embora não de forma exclusiva, adotou predominantemente várias práticas alternativas ao modelo hegemônico de organização.

\section{Palavras-chave}

Organização da resistência; Teoria Política do Discurso; Plano Diretor.

\section{THE ORGANIZATIONAL PRACTICES OF THE DISTRICT OF RATONES IN THE RESISTANCE TO THE PROPOSAL OF "PARTICIPATIVE" LAND-USING PLAN MADE BY THE PREFECTURE OF FLORIANÓPOLIS IN THE LIGHT OF THE POLITICAL THEORY OF DISCOURSE}

\begin{abstract}
In a previous study, it was understood, that could be enhanced an alternative organization, analyzed organizational practices of a resistance movement against the "Participative" Master Plan of Florianópolis City Hall from 2009 to 2011. This movement was attended by several people different areas in the society, among them members of thirteen Municipality districts. Initially, it was believed that in districts where there was a struggle tradition for political participation the resistance organization seemed to be more flexible and differentiated, according to a traditional conception. This was confirmed. However, Ratones District, without this tradition, also showed relevant features of an alternative organization and due to this singularity, it is this organization the analyzing object of this paper. In a way of not victimizing, a strict organization on the studies about social movements it was used the Political Discourse Theory.
\end{abstract}

\section{Keywords}

Resistance organization; Political Discourse Theory; Master Plan. 


\section{Contextualização do Estudo}

Há tempos, discussões a respeito de novas formas de organizar têm despertado a atenção de pesquisadores do campo organizacional; contudo, nota-se que persiste uma curiosidade a respeito de práticas alternativas que signifiquem verdadeiras rupturas com o modelo dominante de conceber organização.

O modelo dominante limita "organização" ao sinônimo de empresa, ou seja, como uma "coordenação racional de atividades de um conjunto de pessoas em busca de algo em comum, objetivos ou regras formais, através de uma cadeia de autoridade e responsabilidade" (Misoczky, 2012, p. 27), o que Solé (2004) afirma ser uma visão teleológica bastante reducionista.

$\mathrm{Na}$ busca por alternativas acerca do organizar, estudos a respeito da resistência às práticas hegemônicas também vêm crescendo, como demonstram os trabalhos de Griggs e Howarth (2000); Contu (2002); Otto e Böhm (2006); Spicer e Böhm (2007); e Spicer e van Bommel (2011); Costa, Guerra, Dourado, Paiva Júnior e Leão (2012); Coelho (2012, 2013).

Em se tratando da organização da resistência, Spicer e Böhm (2007), inspirados em Laclau e Mouffe (1985), chamam a atenção para a dinâmica dos movimentos sociais como importante espaço para melhor análise e compreensão do processo de organização, especialmente sob uma perspectiva macro-organizacional, algo carente nesta seara. Desse modo, depreendeu-se que seria interessante compreender a dinâmica do organizar própria dos movimentos sociais, a organização da resistência, com vistas a proporcionar um alargamento teórico nos estudos no que tange às alternativas na produção do organizar (Cooper \& Burrell, 1988). Ao encontro disso, em Florianópolis, no final de 2008, surgia um movimento de resistência à nova proposta do plano diretor do Município.

Devido a um novo arranjo na política brasileira, houve mudanças significativas nas políticas de planejamento urbano no país nos últimos anos. Um dos marcos neste novo cenário foi a criação da Lei 10.257, de 2001, conhecida como Estatuto da Cidade, que estabelece que os municípios devam envolver a participação comunitária na elaboração de seu plano diretor. Aos municípios brasileiros que se categorizavam na condição de obrigatoriedade do plano diretor, foi dado o prazo de cinco anos para elaboração e aprovação, contado a partir de 10 de outubro de 2001. Como grande parte dos municípios não cumpriu o prazo vencido em 10 de outubro de 2006, a legislação foi alterada concedendo nova data: até 30 de junho de 2008 (redação dada pela Lei 11.673, 2008).

O município de Florianópolis encontrava-se nessa condição, pois há tempo, sobretudo após os anos oitenta começou a surgir uma organização comunitária em favor da preservação do patrimônio cultural e ambiental do município, o qual vinha se mostrando como um expressivo foco de especulação imobiliária e alvo de arbitrariedades políticas. Ao analisar o posicionamento da comunidade após o Estatuto da Cidade, Coelho (2012) constatou em sua pesquisa de doutorado que a falta de entendimento entre Poder Público e comunidade aguçou resistências populares ao planejamento municipal e, até os dias atuais, o plano diretor participativo de Florianópolis não foi aprovado em função de articulações exercidas por diversos atores sociais. O processo de construção do seu plano diretor participativo pode ser dividido em três fases: a primeira marcada pela criação do Estatuto da Cidade e finalizada com a apresentação da proposta de criação do Núcleo Gestor Municipal do plano diretor participativo por parte da Prefeitura (2001 a julho de 2006); a segunda, iniciada com a constituição do Núcleo Gestor Municipal e encerrada com a destituição deste (2006 a início de 2009); e a terceira (2009 a 2011), que se caracterizou fortemente pela resistência à proposta de plano diretor apresentada pela Prefeitura com o respaldo da Fundação CEPA, e pela formação de um Núcleo Gestor Autoconvocado.

Coelho (2012) estabeleceu uma análise das práticas organizativas do movimento de resistência à nova proposta de plano diretor para Florianópolis que se consolida na terceira fase, abordando quando as organizações envolvidas se articularam na linguagem da resistência e como este movimento foi formado e constituído. Para tal, a análise utilizada baseou-se na Teoria Política do Discurso, que ofereceu um olhar alternativo à análise de processos sociais e políticos contemporâneos, bem como permitiu compreender o processo de construção do discurso dominante e o discurso a ele resistente (Laclau \& Mouffe, 1985).

A teoria política do discurso vem se disseminando por diversas esferas da academia. Todavia, Daniel de Mendonça, em 2003, mencionou em seu artigo "A teoria do discurso de Laclau e Mouffe: em direção à noção de significante vazio", que a teoria política do discurso, embora venha influenciando estudos nos círculos acadêmicos norte-americanos e europeus desde os anos oitenta, suas teses ainda são pouco difundidas no Brasil. Nota-se que alguns brasileiros como ele têm focado esforços para investigar a Teoria Política do Discurso, como o próprio Daniel de Mendonça (Universidade Federal de Pelotas - UFPEL), Léo Peixoto Rodrigues (Universidade Federal de Pelotas - 
As práticas organizativas do distrito de Ratones na resistência à proposta de plano diretor

"participativo" feita pela Prefeitura de Florianópolis, à luz da teoria política do discurso

UFPEL), Eloise Helena Livramento Dellagnelo (Universidade Federal de Santa Catarina - UFSC), Joanildo Albuquerque Burity (Universidade Federal de Pernambuco - UFPE), Patrícia Maria Emerenciano de Mendonça (Centro Universitário da Faculdade de Engenharia Industrial - FEI), dentre outros.

Mendonça (2003) destaca a teoria política do discurso como importante ferramenta teórica para análise de sociólogos e cientistas políticos brasileiros. Acredita-se que isso possa se estender aos estudos organizacionais, já que se tem buscado efetivamente alternativas ao modelo tradicional e linear de se investigar as organizações contemporâneas.

Dito isso, nesta pesquisa foram contemplados trinta e nove (39) membros do movimento oriundos dos diversos segmentos da sociedade, tanto do Poder Público como de associações, entidades comunitárias, ecológicas e pessoas da comunidade. Este estudo foi desenvolvido sem uma definição prévia de categorias organizacionais, sendo que estas emergiram a partir do reconhecimento das categorias deslocamento e lógica de equivalência, inerentes à Teoria Política do Discurso (Laclau \& Mouffe, 1985).

Com base nos dados advindos do campo, Coelho $(2012,2013)$ percebeu que as práticas alternativas do movimento em grande parte manifestavam-se em distritos nos quais havia uma história de luta pela participação política na elaboração do planejamento urbano municipal; porém, um dos distritos, o de Ratones, apresentou-se como exceção, haja vista que não tinha tradição em termos de participação, mas servia de referência aos demais pela organização da resistência no contexto estudado.

Diante dessa particularidade, entendeu-se o Distrito de Ratones como uma potencial fonte de dados para a investigação de possíveis práticas organizativas alternativas. Posto isso, este artigo tem como objetivo analisar, à luz da Teoria Política do Discurso, o organizar do Distrito de Ratones na resistência à proposta de plano diretor "participativo" feita pela Prefeitura Municipal de Florianópolis. Para tanto, partiu-se de discussões sobre os estudos organizacionais e a organização da resistência; os movimentos sociais e a dimensão organizacional; e a Teoria Política do Discurso. $\mathrm{Na}$ sequência do texto, contemplam-se os procedimentos metodológicos adotados nesta pesquisa, os resultados obtidos e, por fim, são tecidas algumas reflexões.

\section{Os Estudos Organizacionais e a Organização da Resistência}

O terreno das organizações tem recebido uma influência muito direta de avanços tecnológicos nas esferas produtivas associados à concepção pós-fordista de acumulação flexível, no contexto de economia informacional altamente competitiva, onde se configuram: a flexibilidade de gerenciamento, a individualização, diversificação de relações de trabalho, a descentralização de empresas e sua organização em "redes" (Alves \& Pereira, 2013; Castells, 1997; Hutton \& Giddens, 2004; Taylor, 2014). Esses fatos remetem as organizações a um novo tipo de relação entre Estado e sociedade civil, calcado em políticas neoliberais (Alvarez, Dagnino \& Escobar, 2000).

Entretanto, o que se tem observado é que tais mudanças recentes dificultam, por parte das organizações, as possibilidades a busca de uma perspectiva diferente para leitura e compreensão do social em transformação. Assim, uma alternativa se pauta em abordagens teórico-discursivas com pós-estruturalista sobre o papel do significado em estruturas descentradas, que segundo Cordeiro e Mello (2010), devem assumir como "ponto de partida" a rejeição da noção realista da linguagem como mero epifenômeno, como um meio "neutro" de refletir o mundo ou de descrevê-lo.

Já que o assunto fundamental deste artigo são as práticas organizativas alternativas ao modelo dominante de organizar, cumpre dizer que até as ditas novas teorias administrativas são ainda tributárias das antigas escolas da Administração, sendo que persiste a manutenção das harmonias administrativas e do ethos burocrático (Paes de Paula, 2002). Diante do reconhecimento dos limites de saberes circunscritos ao próprio campo da ciência da Administração, aproximações com outros saberes começam a acontecer.

Misoczky, Flores e Böhm (2008) recomendam que os estudos organizacionais sejam remetidos a novas possibilidades, tanto dentro de campos que adotem uma abordagem processual do organizar quanto de outras áreas disciplinares, com vistas a não apenas negar o gerencialismo, mas a contemplar estratégias de politização da teoria organizacional.

Dito isso, estudos pautados em indagações sobre a prática das isonomias, das organizações substantivas, da economia solidária e de outras configurações organizacionais têm assumido 
importante espaço na referida literatura. Percebe-se, entretanto, que a totalidade da emancipação do homem na esfera do trabalho por meio de um "novo organizar" parece ser dificultada pelo fato de que, mesmo nas tentativas de outras formas de organizar, não há exclusividade de um só tipo de racionalidade na dinâmica das organizações produtivas.

Nota-se que diante dessa configuração dos ambientes organizacionais é interessante compreender, efetivamente, as formas de antagonismos inerentes aos aspectos relacionais e contingenciais das lutas de resistência, bem como suas conexões com diferentes espaços de atuação.

Otto e Böhm (2006) entendem que a resistência é uma articulação de múltiplos antagonismos, onde se encontram imbrincadas a forma de gestão e a dinâmica dos negócios. Dellagnelo e Böhm (2010), porém, ressaltam que embora estes fatores estejam implicitamente presentes na lógica da resistência em função da explanação sobre o processo de construção de ideologias políticas, nem sempre é concedida devida ênfase à complexidade organizacional pertinente às relações hegemônicas. Em consonância, Spicer e Böhm (2007) defendem que o conhecimento das formas de organização para grupos resistirem ao discurso abrangente de gestão torna-se imprescindível. Estes autores questionam a micropolítica e advogam que a resistência pode ser pensada como luta hegemônica empreendida pelos movimentos sociais.

Assim, é perceptível que, apesar de a tradição do modelo burocrático ter impregnado muitas raízes que sustentam um modelo hegemônico de organizar, diversos estudiosos da área organizacional têm focado esforços em temas como resistência e sua dinâmica, por meio de uma lógica interdisciplinar que se utiliza de um suporte político e social para compreender as organizações e os movimentos sociais, que têm representado um fértil campo de análise.

\section{Os Movimentos Sociais e a Dimensão Organizacional}

Frente a essas diversas mudanças no contexto do mundo do trabalho e da emergente relação entre Estado e sociedade civil, torna-se interessante conhecer novos espaços de atuação organizacional, tal como a dinâmica dos movimentos sociais e de seus atores sociais, manifestos em várias lutas: urbanas, ecológicas, antiautoritárias, anti-institucionais, feministas, anti-racistas, étnicas, regionais ou das minorias sociais - que vêm sendo articuladas de maneira inédita (Cordeiro \& Mello, 2010).

Spicer e Böhm (2007), com base em Laclau e Mouffe, chamam a atenção para a dinâmica dos movimentos sociais como importante espaço para melhor análise e compreensão de práticas alternativas de gestão, especialmente sob uma perspectiva macro-organizacional, que reconhece as relações sociais além do âmbito interno das organizações ao incorporar elementos integrantes de uma relação política e envolver práticas articulatórias mais amplas.

De forma semelhante, fica evidente, na literatura sobre movimentos sociais, a fragilidade da dimensão organizacional interna nos estudos acerca da teoria dos movimentos sociais. Coelho e Dellagnelo (2012) investigaram o olhar da Revista Brasileira de Ciências Sociais sobre a dimensão organizacional dos movimentos sociais na última década, e constataram que esse olhar ainda é bastante tímido, pois negligencia muitos detalhamentos acerca dos elementos organizacionais e diversos trabalhos nem sequer referenciavam autores da área organizacional. $\mathrm{O}$ que as autoras suspeitam é que militantes e estudiosos sobre movimentos sociais tenham receio de abordar as formas alternativas de organizar em razão de o modelo hegemônico de organizar ser o gerencial, o que, na visão delas, pode comprometer a fluidez, a imprevisibilidade e a despreocupação com os aspectos teleológicos, pertinentes à essência dos movimentos sociais.

Dentre as principais discussões sobre movimentos sociais, grande parte as remete ao questionamento da sua própria definição. Melucci (1996) alerta que o conceito de movimentos sociais é muito reducionista e o que deveria ser mais frequentemente utilizado é o conceito de ações coletivas. As mesmas envolvem uma estrutura articulada de relações sociais, circuitos de interação e influência, escolhas entre formas alternativas de comportamento; já os movimentos sociais são uma das possibilidades dessas ações.

Dessa maneira, ele defende a ideia de que o movimento social, na condição de categoria analítica, é reservado ao tipo de ação coletiva que: envolve solidariedade; manifesta um conflito; e excede os limites de compatibilidade do sistema em relação à ação em pauta. (Melucci, 1996).

Até o início do século passado, o conceito de movimentos sociais abarcava somente a organização e a ação de trabalhadores em sindicatos (Goss \& Prudêncio, 2004). Entretanto, a partir 
dos nos sessenta, esta abordagem marxista, que priorizava a análise pela categoria de luta de classes, passou a ser indagada por acionalistas, como Alain Touraine, e pelos neomarxistas, como Manuel Castells. Desta forma, o conceito passou a ser um pouco melhor delimitado e, segundo Touraine (1977), os movimentos sociais a serem reconhecidos como o próprio objeto da Sociologia. Isso não significa afirmar que haja um nítido consenso sobre o conceito de movimentos sociais. Em muitos eventos, como: seminários, congressos e palestras sobre o tema, evidencia-se uma significativa confusão semântica, em que os mais variados tipos de ação coletiva são classificados como movimentos sociais.

Com o decorrer dos anos, foi aberta margem ao questionamento da noção unívoca de classe social, embasada na ideia de que muitos sujeitos sociais não se encaixavam mais na configuração tradicional da classe operária (Telles, 1987). Assim, passou-se a investigar a pluralidade dessa nova articulação de sujeitos.

Laclau (1986) aborda a temática dos conflitos sociais ocorridos no passado e os compara com os atuais, destacando as mudanças de comportamento que refletem em uma nova caracterização dos movimentos sociais atuais. Tradicionalmente, os conflitos sociais - intimamente ligados aos movimentos sociais - apresentam três características específicas:

a determinação da identidade dos agentes era feita através de categorias pertencentes à estrutura social", onde "o tipo de conflito era determinado em termos de um paradigma diacrônico-evolucionário; e a pluralidade de espaços do conflito social era reduzida, na medida em que os conflitos se politizavam, a um espaço político unificado, a presença dos agentes era concebida como uma 'representação de interesses' (Laclau, 1986, p. 1).

Cada uma destas características era facilmente visualizada em um conflito social/movimento social, mas o que se percebe é que não há mais uma nítida separação entre as três caraterísticas, é impossível identificar o grupo, concebido como referente, com um sistema ordenado e coerente de posições de sujeito. Exemplificando: devido aos baixos salários, os trabalhadores que eram apenas trabalhadores; atualmente, neste novo cenário, podem ser considerados trabalhadores e consumidores (Laclau, 1986).

No cenário brasileiro, os movimentos sociais tiveram seu ápice na resistência feita à ditadura militar. No entanto, com a Constituição de 1988 energias participativas foram redirecionadas ao interior de novos espaços institucionais que passaram a se configurar, como conselhos gestores e orçamentos participativos, resultantes de reivindicações pela democratização do Estado (SchererWarren \& Lüchmann, 2004). Essas novas institucionalizações e esses novos formatos dos movimentos sociais requerem uma dedicação toda especial por parte de estudiosos.

Posto isso, entende-se que esse espaço, corroborando a afirmativa de Spicer e Böhm (2007), possa servir como um campo fértil de análise de práticas organizativas, já que a necessidade de fluidez e voluntariado desta configuração de organização supostamente clama por um olhar diferente para aquilo que se entende como organização.

É importante frisar que a tentativa de aproximação entre a literatura sobre organizações e sobre movimentos sociais existe, mas há, concomitantemente, muita crítica, pois se percebe a forte influência de teorias de mobilização de recursos, que representam justamente o modelo dominante de organizar. Frente a essa limitação tanto nos estudos organizacionais quanto na teoria dos movimentos sociais, procurou-se uma alternativa na Teoria Política do Discurso para estudar a dinâmica organizacional do Distrito de Ratones na resistência à proposta de plano diretor "participativo" feita pela Prefeitura de Florianópolis.

\section{Teoria Política do Discurso}

Antes de tudo, cabe destacar que as teorias são modelos explicativos da realidade, que tentam construir representações do Real. A ciência funciona baseada na teoria, na tentativa de construir um modelo se aproxime da realidade, seja ela: política, social, econômica ou outra (Popper, 1975).

Laclau e Mouffe (1985), com a teoria política do discurso buscam dar uma resposta a sua preocupação com a precisão epistemológica e metodológica no âmbito das ciências sociais, negligenciada pelo excesso de omissões das ciências racionais. Neste sentido, seguindo a ideia de incompletude, os autores buscam pontos de convergência entre diversas abordagens no esforço para apresentar explicações plausíveis e empiricamente justificáveis do mundo social e político. 
A Teoria Política do Discurso representa uma alternativa teórica e epistemológica na análise de processos sociais e/ou políticos contemporâneos, e reconhece que os processos sociais são resultados de relações formadas por ações e agentes que não são essenciais uns aos outros e que proporcionam, simultaneamente, posições com as quais tais agentes podem se identificar. Um projeto político tentará entrelaçar as diferentes vertentes do discurso em um esforço para dominar ou organizar um campo de sentido de modo a fixar a identidade dos objetos e especialmente as práticas, o que constitui o projeto hegemônico (Howarth \& Stavrakakis, 2000).

A perspectiva de investigação da teoria do discurso de Laclau e Mouffe (1985) inclui a evolução recente da teoria marxista, do pós-estruturalismo e da teoria pós-analítica e psicanalítica. Além disso, embora essa abordagem apoie plenamente as críticas contemporâneas aos positivistas, aos comportamentalistas e aos essencialistas, não se contenta em permanecer em um nível puramente teórico (Howarth \& Stavrakakis, 2000).

A Teoria Política do Discurso teve como ponto de partida um livro do argentino Ernesto Laclau e da belga Chantal Mouffe, chamado Hegemonia e Estratégia Socialista, no qual são propostas algumas categorias de análise, evidentemente, embebidas de práticas organizacionais.

Nessa obra, a noção de hegemonia e de poder são centrais, porque as práticas articulatórias, discursivas, que conseguem se constituir hegemônicas, vão formando uma nova visão, uma nova estrutura de poder, mas também apresentam um caráter de precariedade, de contingência e consequentemente, de durabilidade no tempo que é imprevisível. O social pode ser compreendido sob a perspectiva da construção de ordens discursivas, em que o poder assume papel central e formador de relações sociais. Esta teoria adota a noção ampla de hegemonia, de Gramsci, em que a realidade social é discursiva e tudo pode ser interpretado. A hegemonia é o discurso dominante, porém toda a hegemonia não dá conta de explicar toda a realidade social - ela nega outros sentidos, estabelecendo antagonismos, ou seja, identidades que são negadas pela identidade dominante (Laclau \& Mouffe, 1985).

Os antagonismos, em princípio, encontram-se espalhados pelo campo no que o Laclau (2011) designa lógica da diferença, em que cada um busca suas demandas individuais. Mas pode ocorrer no espaço social um momento de descentramento da estrutura discursiva, ou deslocamento, quando o sentido disponível não explica a experiência dos indivíduos.

A categoria "deslocamento" foi contemplada por Laclau, pela primeira vez em sua obra "New reflections on the revolution of our time", escrita originalmente em inglês em 1990 e traduzido imediatamente ao espanhol. Lacan entra pesadamente na discussão da Teoria Política do Discurso, a ponto de a categoria de antagonismo perder a primazia no sistema de significação e Laclau (1990), então, constrói a categoria deslocamento, que é a marca da impossibilidade da estrutura produzir sentido diante de um momento de crise. O deslocamento é o encontro com o Real, que não é a realidade, uma vez que Laclau (1990) entende que o sistema discursivo se forma na dimensão do simbólico. O Real é o trauma que acontece e que não tem como se explicar e há a necessidade de reorganização da estrutura para lidar com tal trauma.

Então, diante do deslocamento da estrutura discursiva, as demandas passam a se contatar por meio de uma prática articulatória, de um processo de identificação e de construção da chamada lógica de equivalência, que ocorre quando tais demandas percebem a existência de pontos comuns com outras ainda (Mendonça, 2003).

A lógica de equivalência ocorre em torno de um ponto nodal, que é um ponto de referência em um discurso que une um sistema especial de significado ou cadeia de significação (Laclau \& Mouffe, 1985). O ponto nodal é formado por um significante vazio, a saber, um termo que não tem um significado específico (Laclau, 2011). No entanto, o autor se questiona como que um significante que não esteja ligado a significado algum continue integrando um sistema de significação e crê que para que o significante vazio não se torne uma mera sequência de sons, desprovido de função significativa, ou seja, não se torne excessivo, é necessário que, por meio da subversão do signo, aconteça algo interno ao processo de significação.

A partir da união em torno de um ponto nodal constituído de um significante vazio, é firmada a luta contra-hegemônica, a disputa pela fixação do sentido para desposicionar o sentido atual e reposicionar outro, conforme as experiências que os atores sociais passam em determinada ocasião.

Mediante a vontade de analisar as práticas organizativas do específico Distrito de Ratones em uma fase de resistência à proposta de plano diretor feita pela Prefeitura de Florianópolis, entendeuse que a Teoria Política do Discurso fosse uma interessante possibilidade de análise, haja vista que as categorias apresentadas por Laclau e Mouffe (1985), fruto de uma história de estudos dos 
mesmos, permitiam um olhar diferenciado ao organizar, que possibilita uma transcendência das amarras de um modelo dominante de organizar, embasado em divisão de trabalho, linhas de comando, hierarquia etc. Não que essas práticas não pudessem emergir do campo, porém a liberdade de expressão na utilização desta teoria como pano de fundo, tenderia a ser maior.

Como no referido distrito, em princípio, havia muitas demandas individualizadas, que constituíram uma identidade de movimento frente à resistência a aprovação da proposta de plano que divergia das aspirações das pessoas que lá habitam, as categorias deslocamento e lógica de equivalência se mostraram convergentes com a perspectiva de análise que se propunha adotar.

\section{Os Procedimentos Metodológicos}

Como o objetivo primordial deste estudo é analisar, no contexto do Distrito de Ratones, práticas organizativas alternativas ao modelo dominante de organizar, na realização da resistência à proposta de plano diretor feita pela Prefeitura Municipal de Florianópolis, buscou-se ir a campo com categorias da Teoria Política do Discurso, que fundamenta este estudo epistemologicamente.

Entende-se que seria inviável definir previamente categorias de análise advindas do campo da Administração para investigar as práticas organizativas, uma vez que o próprio vício de linguagem poderia induzir os participantes da pesquisa a declararem dados que na sua essência não refletiram o seu organizar.

Diante dessa intencionalidade, este artigo teve como alicerce uma abordagem predominantemente qualitativa, com finalidade interpretativa. Foram realizadas treze (13) entrevistas semiestruturadas, entre agosto e dezembro de 2011, com amostra composta por: um (1) representante distrital, dois (2) participantes do Poder Público, dois (2) membros da associação de pescadores, (2) da associação de moradores, (1) de entidade ecológica e (5) pessoas da comunidade. Os participantes foram escolhidos intencionalmente e, para isso, foi usada a técnica de bola de neve até se atingir um ponto de saturação. Para efeito de preservação de anonimato, os participantes desta pesquisa são designados pela letra "P" seguida de numeração de 1 a 12 , como segue: P1 - representante distrital; P2 - IPUF; P3 - Prefeitura; P(4 e 6) - Associação de Moradores de Ratones; P5 - Associação de Pescadores do Rio Ratones; P7 - Entidade Ecológica; P(8 a 12) membros da comunidade.

Cada entrevista levou em média 2 horas e todas elas - assim como as palestras, os seminários e os congressos relacionados ao tema - foram gravados e transcritos na íntegra. Como dados secundários foram analisados folders, relatórios, atas de reuniões e audiências públicas, entrevistas concedidas na mídia televisiva, cartilhas, legislação nacional sobre política urbana, Estatuto da Cidade, resoluções do Conselho das Cidades, propostas de diretrizes comunitárias, anteprojeto de lei da Prefeitura, teses, dissertações, livros e revistas técnicas. Também foram transcritas as falas dos ministrantes dos Congressos da Cidade e de algumas reuniões do Núcleo Gestor Municipal Autoconvocado.

Além disso, adotou-se a técnica da observação direta, respaldada por um diário de campo, onde constaram: a descrição dos sujeitos e dos locais, bem como a transcrição dos diálogos em termos de gestos e demais reações dos sujeitos desta pesquisa. Posto isso, esta abordagem permitiu que essas reações dos sujeitos envolvidos no processo de construção do plano diretor de Florianópolis fossem confrontadas com as menções em entrevistas, assim como o registro aspectos relativos a fatos e comportamentos diretamente ligados ao fenômeno pesquisado.

O roteiro de entrevista utilizado nesta pesquisa foi o mesmo já aplicado na pesquisa de doutorado de Coelho (2012), a qual estudou todos os distritos de Florianópolis e demais segmentos que compunham o movimento de resistência à elaboração de um Plano Diretor sem participação política da comunidade.

Ao zelar pela dinamicidade e fluidez da dimensão organizacional da resistência, não foram descartadas novas possibilidades de análise. Com o desenvolvimento do estudo, as categorias puderam ser ratificadas, devido à coerência com o fenômeno estudado e incrementados indicadores que facilitaram e subsidiaram uma melhor compreensão das categorias em pauta.

O estudo teve como fundamento duas categorias da Teoria Política do Discurso: o deslocamento e a lógica de equivalência. A seguir são apresentadas suas definições constitutivas e operacionais (Figura 1). 


\begin{tabular}{|c|c|c|}
\hline CATEGORIAS & $\begin{array}{c}\text { DEFINIÇÕES } \\
\text { CONSTITUTIVAS }\end{array}$ & DEFINIÇÕES OPERACIONAIS \\
\hline $\begin{array}{c}\text { Efeitos } \\
\text { deslocatórios }\end{array}$ & $\begin{array}{l}\text { São fatores que levam à } \\
\text { visibilidade da contingência } \\
\text { das estruturas discursivas } \\
\text { (Laclau \& Mouffe, 1985). }\end{array}$ & $\begin{array}{l}\text { - Fatos marcantes na história de luta } \\
\text { - Momentos em que o discurso hegemônico } \\
\text { passou a não fazer sentido às diferentes } \\
\text { demandas }\end{array}$ \\
\hline $\begin{array}{l}\text { Lógica de } \\
\text { equivalência }\end{array}$ & $\begin{array}{l}\text { É a criação de identidades } \\
\text { equivalentes que expressam } \\
\text { pura negação de um sistema } \\
\text { discursivo (Laclau \& Mouffe, } \\
\text { 1985). }\end{array}$ & $\begin{array}{l}\text { - Relação entre as demandas envolvidas no } \\
\text { plano diretor de Florianópolis } \\
\text { - Significantes vazios } \\
\text { - Antagonismos }\end{array}$ \\
\hline
\end{tabular}

Figura 1 - Categorias de análise e suas definições constitutivas e operacionais Fonte: Coelho, 2012.

Mediante a análise destas categorias, emergiram vários aspectos organizacionais manifestados nas práticas de articulação da resistência, ou seja, no estabelecimento de uma relação entre os elementos do discurso, em que a identidade dos atores sociais deu origem a uma nova identidade de pertencimento (Barros, 2009). Seguem os elementos organizacionais emergentes do campo analisado nesta pesquisa (Figura 2).

\begin{tabular}{|c|c|}
\hline DADOS DO CAMPO & $\begin{array}{c}\text { ASPECTOS ORGANIZACIONAIS } \\
\text { EMERGENTES }\end{array}$ \\
\hline $\begin{array}{l}\text { - Formas de manutenção da organização } \\
\text { - Cobranças entre os membros } \\
\text { - Rotinas internas }\end{array}$ & Organização das atividades \\
\hline $\begin{array}{l}\text { - Troca de informações nos distritos/entidades e entre eles: } \\
\text { - Formas adotadas } \\
\text { - Meios mais utilizados } \\
\text { - Alternativas procuradas }\end{array}$ & Comunicação \\
\hline $\begin{array}{l}\text { - Dinâmica da escolha das pessoas que representavam a } \\
\text { comunidade } \\
\text { - Características de personalidades de destaque } \\
\text { - Formas de influência dos membros do movimento }\end{array}$ & Liderança \\
\hline $\begin{array}{l}\text { - Perfil das pessoas que participam do processo } \\
\text { - Forma de incentivo à participação } \\
\text { - Conteúdos das sugestões } \\
\text { - Modo de encaminhamento das sugestões } \\
\text { - Papel do representante no incentivo à participação } \\
\text { - Origem do representante da organização } \\
\text { - Eventos de apoio à participação } \\
\text { - Atuação da comunidade }\end{array}$ & Participação \\
\hline $\begin{array}{l}\text { - Responsabilidades assumidas } \\
\text { - Determinações em nível operacional } \\
\text { - Escolhas acerca de assuntos mais relevantes }\end{array}$ & Tomada de decisão \\
\hline
\end{tabular}

\section{Figura 2 - Dados do campo e aspectos organizacionais emergentes na pesquisa}

Fonte: elaborada pelos autores (2014).

Neste estudo, o que se designa como prática alternativa não significa que seja totalmente inédita ou inusitada no campo organizacional, mas sim alternativa ao modelo dominante de organizar, que segundo Misoczky (2012) tem reduzido a organização ao sinônimo de empresa. Parte-se do pressuposto de que a produção do organizar transcende o conceito de organização da produção (Cooper \& Burrell, 1988). Diante disso, ao reconhecer que os termos utilizados na Administração são impregnados de uma forte carga ideológica pautada no cálculo e na racionalização do trabalho, buscou-se, durante as entrevistas, utilizar termos neutralizados do domínio do modelo tradicional e instrumentalista de organizar. O próprio termo "Administração", etimologicamente, já cunha a noção de submissão no contexto da organização. Epistemologicamente, neste trabalho, a ideia que se sustenta é a de que o mundo organizacional não precisa ser empresarizado para dar certo (Solé, 2004).

Estas práticas voltadas à organização do movimento foram, então, convencionalmente, reunidas em: organização das atividades, comunicação, liderança, participação e tomada de decisão. Cabe comentar que ao se abordar os sujeitos da pesquisa, foi concedida devida atenção para não serem abordados termos peculiares à área da Administração. 
As práticas organizativas do distrito de Ratones na resistência à proposta de plano diretor

"participativo" feita pela Prefeitura de Florianópolis, à luz da teoria política do discurso

Diante da transcrição das entrevistas e do áudio dos eventos, as categorias de análise, os seus desdobramentos e, principalmente, os aspectos organizacionais que emergiram do campo foram alocados e tratados de forma categorial (Bardin, 2009).

\section{Resultados do Estudo}

Antes de tudo, cabe fazer um breve comentário sobre o planejamento urbano de Florianópolis. O município já teve três planos diretores: o de 1954, o de 1976 e o de 1997, sendo este vigente até os dias de hoje. Historicamente, a comunidade não participou desses planos e muitos equívocos ao longo do tempo fizeram com que, hoje, Floripa, carinhosamente assim chamada por seus moradores, pague o preço de uma cidade repleta de vulnerabilidades e fragilidades no que diz respeito ao seu planejamento urbano.

Nas últimas décadas, a noção de gestão do espaço urbano foi tomada por uma atmosfera de incertezas, em que um plano mais coerente passava a ser um plano menos técnico, mais participativo, mais integrador da sociedade. Nesse sentido, em 2001 foi promulgada a Lei Federal 10.257, chamada de Estatuto da Cidade, determinando que o plano diretor seja elaborado com a participação comunitária e nos termos de lei municipal.

Após o marco do Estatuto da Cidade, pode-se dividir o processo de elaboração do plano diretor de Florianópolis em três fases, como já se mencionou na primeira parte deste artigo, sendo a última fase, a da resistência, o enfoque deste estudo.

A primeira fase (2001 a 2006) foi marcada pela obrigatoriedade da participação comunitária na construção dos planos diretores, prevista pelo Estatuto da Cidade. O Poder Público, em 2003, tentou fazer uma Conferência da Cidade sem divulgá-la à população. A população soube e reagiu. Houve, então, duas conferências: uma organizada pela Prefeitura e, outra, com a participação das comunidades. Somente em 2005 realizou-se uma conferência de acordo com os moldes do Estatuto da Cidade, e o prazo para elaboração do plano diretor participativo já estava vencendo. Em tal ocasião, foram eleitas lideranças comunitárias para compor o Conselho da Cidade (ConCidade), com o objetivo de discutir as políticas. No final desta fase, foi constituído o Núcleo Gestor Municipal, fonte de muitas lideranças eleitas para o Conselho.

Na segunda fase (2006 a início de 2009), houve uma espécie de apoio institucional da Prefeitura à formação do Núcleo Gestor Municipal, formado por vinte e seis (26) membros, onde cinco (5) seriam pessoas ligadas a segmentos sociais, mais um (1) representante de cada distrito, sendo o Município divido em treze (13) distritos, o que totalizava trinta e nove (39) representações. Este núcleo teve como um de seus objetivos fiscalizar o processo de construção do plano diretor para garantir que este fosse participativo de fato. A Prefeitura apoiou os núcleos distritais com um "kit de apoio" composto por uma base distrital, um computador, um aparelho celular com conta subsidiada, um estagiário do IPUF e o acompanhamento de um técnico do IPUF.

Nesta fase, foram levantadas demandas e diretrizes comunitárias pelos treze (13) distritos municipais e setores ligados às universidades, movimentos sociais, categorias profissionais e empresariais. Além das reuniões quinzenais que aconteciam nos distritos, essas demandas também eram discutidas quinzenalmente nas reuniões do Núcleo Gestor Municipal, bem como nos Congressos da Cidade, eventos organizados pelos membros do movimento Demandas e diretrizes apontadas pelas comunidades foram entregues à Prefeitura, para aprovação em audiência pública. Sem uma metodologia específica, os estagiários do IPUF sintetizaram as inúmeras diretrizes em trinta e três (33), que foram apresentadas em audiência pública em 03 dezembro de 2008.

No começo de 2009, o Núcleo Gestor foi destituído, as bases distritais retomadas e os equipamentos fornecidos aos distritos reavidos pela Prefeitura, sob o argumento de que a participação popular se restringia à fase de leitura comunitária, já que a população não tinha conhecimento técnico das demandas. Não bastasse isso, a Prefeitura contratou uma empresa argentina de consultoria, chamada Fundação CEPA, para elaborar uma proposta de plano em princípio baseada nas demandas e diretrizes levantadas. A partir daqui, dois blocos hegemônicos ficaram bem delimitados: os empreendedores e os sociais, como denominados por alguns entrevistados - o que Santos (2007) chama de cidade-mercado e cidade-direito.

Frente a esses acontecimentos, inicia-se a terceira fase (2009 a 2011) do processo, a fase da resistência ao Plano da CEPA. O maior momento de deslocamento foi a destituição do Núcleo Gestor, pois a arbitrariedade e a violência empregadas pelo Poder Público fez com que o discurso da Prefeitura não abarcasse mais os sentidos das demandas. Também houve outro momento de 
descentramento da estrutura discursiva do Poder Público: no Clube Doze de Agosto, no final de 2009, foram apresentadas as diretrizes levantadas pela CEPA e a proposta em quase nada convergia com a leitura comunitária feita de 2006 a 2008, sendo que alguns quesitos fugiam integralmente dos interesses da população.

Um dos fatos marcantes desta fase foi a "tomada do TAC", onde membros do movimento tomaram o teatro e impediram uma audiência para referendar o processo participativo do plano diretor de Florianópolis baseado na proposta da CEPA. Evidenciaram-se os significantes vazios "participação" e "'não' ao plano", onde os discursos de vários atores sociais contrários à proposta da CEPA, anteriormente dispersos no campo da discursividade, lograram uma nova identidade no momento em que suas demandas foram unidas em pontos nodais fundamentais, em torno destes significantes vazios (Laclau, 2011).

Com base nisso, foram formados pontos nodais constituintes de uma cadeia de equivalência que contemplou interesses de diversos grupos, como: Associação Florianopolitana de Voluntários (AFLOV), Associação Florianopolitana de Deficientes Físicos (AFLODEF), "sem-teto", sindicatos, pescadores, maricultores, entidades ecológicas, entidades comunitárias e ambientalistas. Esses grupos perceberam que o plano proposto divergia de seus interesses quanto à questão da sustentabilidade e, assim, anularam as suas diferenças em uma cadeia de equivalência - ou seja, a partir de identidades que anteriormente operavam sob a lógica da diferença, assumiram a lógica de equivalência. A partir disso, foram criados um Comitê Interuniversitário e um Núcleo Gestor Autoconvocado composto por representantes dos segmentos da sociedade que reivindicavam continuar participando da elaboração do plano diretor, embora o núcleo não fosse mais legitimado pelo Poder Público Municipal.

Ao analisar os momentos de ruptura com o discurso da Prefeitura e a formação da lógica de equivalência do modelo de resistência, foram identificadas as práticas organizativas adotadas pelos grupos. Observou-se, de acordo com os dados emergentes do campo, que grande parte das práticas alternativas de organizar era oriunda de distritos com uma história de luta pela participação política. O Distrito de Ratones, embora não contasse com esse histórico de luta, destacou-se e recebeu o respeito dos demais distritos por sua atuação e organização da resistência à proposta do plano, razão pela qual suas práticas são alvo de reflexão neste artigo.

\subsection{O Distrito de Ratones}

De acordo com a Lei 620 de 21/06/1934, o Distrito de Ratones foi criado ao se desmembrar de outro distrito de Florianópolis, chamado Santo Antônio de Lisboa. O Distrito de Ratones situa-se a oeste da llha de Santa Catarina, à distância de dezessete quilômetros do centro de Florianópolis em direção ao norte da llha. Caracteriza-se por um quadro ambiental relativamente conservado de seus $32,4 \mathrm{~km}^{2}$, onde $31 \%$ são de mata densa e $23 \%$ estão no estágio de capoeira (Cardoso, 2001). É o único distrito de Florianópolis que não tem acesso ao mar.

Localizado em uma área plana, é cercado por morros de altitudes variadas que chegam a alcançar 415 metros, enquanto na área considerada plana apresenta variação de nível de 1 a 10 metros. Formado pelas comunidades da Vargem Pequena e Ratones, incluindo as localidades do Canto do Moreira e da Cachoeira da Florinda, apresenta baixa densidade demográfica e é estruturado linearmente ao longo da sua Estrada Geral (P1).

A economia do distrito cresceu com base na agricultura de subsistência e na troca do excedente com outras localidades. Até os dias de hoje, preserva muitos traços culturais do período de sua colonização e mantém suas características de área rural com o cultivo de atividades primárias como agricultura, pecuária, artesanato e turismo ecológico (Nascimento, 2008).

Quanto à infraestrutura de equipamentos públicos, no Distrito de Ratones esta é bastante precária, composta pela Escola de Ensino Fundamental Mâncio Costa, Creche Hermenegilda Jacques, Creche da Vargem Pequena, Centro de Saúde de Ratones, Centro de Saúde da Vargem Pequena, Cemitério de Ratones e Intendência Distrital. Ressalte-se que não há áreas públicas de lazer ou áreas verdes comunitárias (E4).

Além dos nativos da região, a população é composta por muitos migrantes de outras regiões do Município que construíram sítios e chácaras em busca de um convívio bucólico e de qualidade de vida. O fato despertou o interesse do segmento imobiliário, que luta para aprovar concessões para a construção de condomínios e outros empreendimentos na região. Diante disso, a população tem buscado discutir alternativas para que não haja graves consequências em termos de saneamento, água e questões subjacentes. 
Mais características são apresentadas no decorrer dos relatos acerca dos deslocamentos e da formação da lógica de equivalência, que alicerçam a análise das práticas organizativas do distrito na fase da resistência à proposta de plano diretor da Prefeitura.

\subsubsection{Efeitos deslocatórios, lógica de equivalência e práticas organizativas do distrito de Ratones}

Dentre os atores socais que compõem o distrito, foram observados diversos interesses, demandas e identidades. Por exemplo, P5, da Associação de Pescadores do Rio Ratones, ressaltou a preocupação com os direitos dos pescadores, a valorização da cultura de Ratones e a preservação do meio ambiente por meio da fiscalização e da exigência de medidas necessárias para proteção do Rio Ratones, por parte de orgãos responsáveis. Durante a sua fala, deixou clara a preocupação que a associação tem com o manguezal do Rio Ratones, integrante da Reserva Ecológica dos Carijós.

O Estatuto da Associação de Moradores de Ratones, criado em 1995, prevê no art. $4^{\circ}$ que a associação deve:

a) ser autônoma e independente com relação aos credos religiosos, aos partidos políticos, ao Poder Público e às organizações privadas;

b) ter a democracia como regra básica de funcionamento;

c) defender o pluralismo, assegurando liberdade de defesa de ideias e unidade na execução das decisões da Associação;

d) lutar contra todas as formas de dominação, alienação e desrespeito aos direitos humanos e sociais; e

e) promover a organização e estimular a participação dos associados a partir das reivindicações e interesses coletivos.

Esses princípios ficaram bem evidentes nos trechos proferidos pelo P6, membro da Associação de Moradores de Ratones, quando este enfatiza, em tom de voz mais elevado, a necessidade de preservar a integridade política e participativa dos seus associados. Todavia, comenta que "isso até acontecia antes do Estatuto da Cidade, mas não se tinha uma visão de cidade como se tem hoje. A gente só via o bairro em si..." (P6). Com a criação do Núcleo Gestor Municipal, a interação entre os diversos distritos facilitou a construção da identidade do movimento como um todo.

Um morador, P9, diz que

os moradores querem mesmo é manter a capacidade de água e esgoto, sem se preocupar com a invasão imobiliária e com a vinda desse monte de hotel fazenda. Eles pensam que porque a região é formada por gente simples e sem estudo, a gente não sabe reivindicar e se fazer ouvir frente ao Poder Público Municipal (P9).

P7, que é membro de uma entidade ecológica, a União Florianopolitana de Entidades Comunitárias (UFECO), acredita que o Distrito de Ratones,

por ter suas peculiaridades, pode, sim, pensar em progredir. A renda per capita lá é muito baixa. Mas isso só acontecerá se for de forma bem planejada e se o critério social também vier à tona. O crescimento por si só será como um tiro no pé.

Mas, para o morador P10, essa discussão entra em conflito quando envolve os interesses de muitos nativos que percebem em suas simples moradias um negócio viável para mudar de vida, economicamente falando.

Sou pobre, minha senhora. Durante a minha vida toda passei dificuldade para criar meus três filhos e meus dois netos e, agora que posso vender minha propriedade valendo um dinheirinho, para eu morrer bem, vem esse pessoal do plano diretor para criar "pobrema" [ sic] (P10).

Ao se tratar dos interesses dos atores sociais do distrito, cabe destacar a história de conflitos entre os moradores da Vargem Pequena e de Ratones. "Há cem anos, tinham os bailes, as pessoas iam de carroça e aí tinha um grupo da Vargem Pequena que ia lá ao baile de Ratones e estragava o baile... Coisa cultural mesmo" (P1). 
Essa herança cultural era um problema a ser trabalhado pelos organizadores do distrito, mas foi contornada diante da necessidade de eleger um representante distrital em 2006, uma vez que se conseguiu compor uma chapa eclética, representada por três nomes: um da Associação de Moradores de Ratones, um da Associação de Pescadores e um da Associação da Vargem Pequena.

A conversa foi tranquila. Como a gente foi o único distrito municipal que para eleição de representante distrital teve uma chapa por aclamação. Não teve eleição! Nós fizemos uma composição para esses três nomes e fizemos uma chapa que foi indicada e que não teve disputa. Teve uma aclamação. Então, divergência existe; mas a gente trabalha sempre pelo comum (P1).

Tal composição de representação se manteve na fase da autoconvocação e, nos dias de hoje, existe muito respeito entre eles. Segundo P1, a desavença histórica passou apenas a integrar o passado formador do Distrito de Ratones. Todavia, à luz da observação direta foi possível notar que conflitos entre membros do distrito existem, mas os motivos passaram a ser outros, como a concepção sobre a especulação imobiliária, como se percebe no relato de P10. O consenso pela preservação do meio ambiente no município é fato, mas quando passa a se tratar da sua propriedade particular, muitos defendem a vinda de empreendimentos para o distrito de Ratones.

Ao analisar as demandas e diretrizes registradas em atas de audiências deste Distrito na fase de 2006 a 2008, notou-se que grande parte dos interesses converge para a manutenção das características rurais do distrito, uma vez que tal manutenção evitaria desgastes ambientais, favoreceria o turismo sustentável e manteria a tranquilidade bucólica do local. O principal antagonismo evidencia-se no setor imobiliário, que se mantém em estado de alerta para, diante de qualquer brecha legal, agir por meio do que intitula "segurança jurídica".

Tendo em vista os dois momentos de deslocamento observados no movimento e no cerne do distrito - a destituição do Núcleo Gestor Municipal oficialmente constituído e a contratação da CEPA , a comunidade não se via mais representada pelo discurso do Poder Público. O discurso não fazia mais sentido para as diversas demandas do Distrito de Ratones (Laclau \& Mouffe, 1985). Havia o medo do comprometimento da sustentabilidade na região e um desgosto muito expressivo com o desprezo da leitura comunitária feita pelo distrito durante os dois anos anteriores.

Diante dos interesses, convergências e divergências no decorrer do processo de elaboração do plano diretor do Município, constatou-se que as identidades dos segmentos nos dois momentos de deslocamento foram anuladas ao entrar em contato umas com as outras, unindo-se em torno de um ponto nodal, constituído dos significantes vazios: “Sustentabilidade, participação e 'não' ao plano da CEPA", formando-se uma cadeia de equivalência (Mendonça, 2003), já que, sem participação e com a contratação da CEPA, não poderiam mais lutar por grande parte de suas demandas.

Por meio do reconhecimento dos momentos de deslocamento e da constituição das lógicas de equivalência, foram observadas as práticas organizativas do distrito e emergiram do campo dados sobre organização de atividades, comunicação, liderança, participação e tomada de decisão.

Com o fim do Núcleo Gestor Oficial, houve a retomada do kit de apoio fornecido pela Prefeitura. Assim, as atividades do Núcleo Gestor Autoconvocado só eram efetivadas com o patrocínio de recursos dos integrantes dos distritos. Os membros do Núcleo Distrital de Ratones tiveram que, na medida do possível, usar seus próprios recursos materiais e humanos para dar sequência à resistência à proposta de plano diretor vinda da Prefeitura.

Até um determinado momento da segunda fase do processo, o distrito dispunha de um espaço na Escola Estadual Durval Melquíades de Souza. Mas a situação mudou de contexto, conforme relata P1:

[...] houve uma parceria do governo do Estado com o município e houve uma municipalização dessa escola. Aí a gente teve um problema com a direção da escola, que não queria mais a base distrital lá, e pediu para a gente sair. Depois disso ainda o IPUF arrumou um espaço para a gente, mas depois houve um problema no contrato de aluguel. A gente não conseguiu mais fazer. Fomos para uma casa - tinha um morador do distrito que nos cedeu o espaço para fazer aquilo lá de base distrital. Então, a gente está achando maneiras de se instalar lá enquanto base distrital. (P1)

Foi, portanto, com o apoio dos moradores que se conseguiu espaço para a realização de reuniões e audiências. Embora algumas pessoas do Distrito de Ratones tenham se decepcionado com o desleixo da Prefeitura com a leitura comunitária realizada na fase anterior e, por isso, abandonado o movimento, as pessoas que permaneceram no movimento buscaram compensar as dificuldades geradas pela falta de apoio institucional com o voluntariado de seus integrantes. A 
As práticas organizativas do distrito de Ratones na resistência à proposta de plano diretor

"participativo" feita pela Prefeitura de Florianópolis, à luz da teoria política do discurso

partir disso, grande parte das discussões começou a ser realizada na Associação de Moradores de Ratones. Como o poder aquisitivo da comunidade é considerado baixo, buscava-se desenvolver o trabalho com o mínimo de dispêndio e, quando isso não era possível, contava-se com os recursos de voluntários membros do distrito e com a renda de eventos promovidos pelo Núcleo Gestor Municipal Autoconvocado.

Não que na segunda fase viesse algo específico para Ratones; mas, geralmente, conseguiam verbas e disponibilizavam alguma ajuda aos distritos para construir faixa, banners etc., em prol da luta contra a "não participação" (P4).

Além dos representantes do distrito ou os representantes de classes, quem passou a fazero controle dos poucos recursos na fase do Núcleo Gestor Autoconvocado foram osos próprios moradores, que embora não assumissem uma função específica permaneciam à disposição para auxiliar na organização. Como se vê, não havia uma designação de pessoas - "havia uma política de respeito e de confiança mútua" (P11).

Dentre as atividades na fase da resistência destacavam-se a organização de mobilizações com confecção de faixas, cartazes, banners, elaboração de folders em prazo recordes, contato com grupos em busca de patrocínio, acompanhamento de decisões judiciais sobre a possível retomada do plano, auxílio à organização de reuniões no distrito e a eventos promovidos pelo Núcleo Gestor Autoconvocado. Como o representante distrital predispunha de seu tempo e vontade para frequentar as reuniões do referido núcleo, eles se comprometiam a levar as demandas do distrito bem como a repassar todas as informações do processo de construção do plano diretor, por meio da Associação de Moradores, com vistas a manter a comunidade de Ratones informada a respeito das novidades sobre o planejamento urbano do Município e, consequentemente, do que the poderia ser ocasionado. Mas todas as pessoas do distrito eram convidadas a participar da reunião do Núcleo Gestor Autoconvocado e muitas pessoas da comunidade passaram a acompanhar o representante na participação do distrito neste núcleo.

Em cada reunião alguém se prontificava aestipular e dar andamento às atividades nos quinze dias subsequentes, já que o grupo se reunia quinzenalmente. Depois de um tempo, as reuniões passaram a acontecer com frequência menor. Se a pessoa designada não desse conta de fazer as atividades, outros voluntários imediatamente se dispunham a ajudar, já que não havia uma divisão de atividades. Isso foi diferente da segunda fase, onde se buscava dentro do grupo as pessoas que pudessem ajudar em determinadas questões - a ideia, na época, era trazer os moradores antigos, que andaram por todos aqueles morros e conheciam todos os rios da região para poder colaborar com o processo. Buscava-se identificar o que cada um tinha de melhor para contribuir naquela parte específica do processo, para incremento da leitura comunitária; porém, nesta terceira fase, não.

Segundo P4, no distrito havia um gargalo que impedia o avanço no trabalho do plano diretor. Não dava para planejar o resto dos aspectos técnicos sem a clareza do que não podia ser feito. Mas “a gente sabia que além da parte técnica, a política precisava estar forte no contexto do distrito para que, quando se voltasse a discutir junto à Prefeitura, a gente estivesse bem engajada" (P4).

O trecho de uma das entrevistas revela que os membros do distrito sentiam-se reprimidos na fase anterior do processo por causa da obrigação de elaborar atas: "Uma coisa boa dessa fase (terceira) é que a gente não precisava montar aquelas coisas de atas, de relatórios e tudo mais... Aquilo era para acabar com o cara" (P6).

Isso reflete o fato de que não havia uma delimitada divisão de trabalho, a configuração organizacional se aproxima de alternativas mais autogestionárias pautadas na colaboração mútua, onde explicitamente se clamava pela iniciativa de vários segmentos, os quais compartilhavam suas propriedades privadas em favor dos encontros, realizavam as atividades com base na cooperação e não designação previamente funções a serem exercidas em favor da resistência.

Posto isso, depreende-se que, de modo predominante, a organização das atividades inerentes ao processo de resistência à construção de forma não participativa do Plano Diretor de Florianópolis, no contexto de Ratones, apresenta alguns indícios que rompem com o modelo dominante de organizar, como: a concessão de recursos privados para a manutenção do movimento e a não divisão do trabalho, uma vez que a coletividade funcionou de maneira cooperativa sem a necessidade de designação prévia de responsabilidades.

A troca de informações na referida fase também contou com a importante disposição do representante distrital, seus suplentes e também de demais membros da comunidade em gastar, ou melhor, investir, em contas telefônicas e panfletos, e em abastecer os blogues das associações. 
A maneira mais fácil de trocar informação, nesta fase, foi através de um grupo de e-mail. A gente tem o ND Ratones, que é um grupo de e-mails que funciona até hoje. Sempre que tem alguma informação, a gente passa. Infelizmente, a gente não atende todo mundo porque tem muita gente que mora lá que não tem acesso a e-mail, que não tem uma inclusão digital, e aí é telefone. Antes [ na segunda fase], a gente tinha um telefone que a gente sempre ligava convidando para reunião; mas com a autoconvocação, precisamos usar nossos telefones. (P1)

Foi criado um grupo de e-mails para o Núcleo Gestor Autoconvocado, ou seja, extraoficial para que não houvesse interferência e agregação de membros do Poder Público e demais membros favoráveis à aprovação do Plano da CEPA, e as pessoas ficassem mais à vontade, favorecendo uma participação mais fluida. Todavia, por meio do confronto entre os dados das notas de campo e os das entrevistas, constatou-se que o grupo de e-mail, apesar de ser considerado um meio efetivo de contato, não atingia a maior parte da população do distrito, pois muitos não tinham acesso a computador. Outros tinham o equipamento em casa, mas quem sabia utilizá-lo eram os filhos. A mesma dificuldade era percebida no acesso ao blogue do distrito (P9).

Dessa forma, os organizadores resolveram pedir aos agentes de saúde que divulgassem as reuniões e transmitissem as informações, no intuito de despertar o interesse da população na participação política (P5). As mensagens passadas tanto via internet como por meio de contato pessoal clamavam por participação nas reuniões do distrito e utilizavam slogans como "Traga seu vizinho!" e "Além de vir, traga mais um", buscando ampliar a participação.

De acordo com P1, como o movimento não tinha uma metodologia padrão a ser seguida pelos distritos, cada um deles tentou se adaptar às suas peculiaridades locais. No Distrito de Ratones, por exemplo, adotou-se esta lógica para construir as reuniões:

A ideia era ir até a comunidade, e não trazer a comunidade até a gente. Eu tenho um perímetro ali na comunidade de Ratones para mais de vinte quilômetros. Então se eu quisesse trazer alguém da Vargem Pequena para fazer uma reunião no centrinho de Ratones, não ia ninguém. Então nós dividimos em microzonas com a densidade populacional, e fizemos sete reuniões. Depois fazíamos uma audiência geral na comunidade para fazer todo esse fechamento e em cima dessas intenções. Mas essa era uma metodologia, específica de Ratones. Não sei se em outros distritos foi assim... (P1)

Para relacionamento com outros distritos e demais segmentos externos, também havia o grupo de e-mails extraoficial do Núcleo Gestor Autoconvocado, redes sociais e fóruns como o Fórum da Cidade $^{3}$ e o COMINTER ${ }^{4}$. Estes meios alternativos de comunicação emergiram da necessidade de rejeição de valores políticos dominantes e do interesse de possibilitar um diálogo criativo entre os membros do movimento (Frenzel, F., Böhm, S., Quinton P., Spicer A., Sullivan, S. \& Young, 2011).

A imprensa se fez pouco presente na terceira fase, sendo que a mídia televisiva e impressa de Florianópolis se apresentaram apenas nos momentos de resistência do movimento focando o vandalismo das manifestações públicas. Apenas o programa "Conversas Cruzadas", da TVCOM, oportunizou debates. O representante distrital de Ratones participou de muitas palestras, eventos, congressos e outros focos de discussão, conquistando o respeito e a admiração não só dos membros do movimento, como também do Poder Público Municipal.

Então, pode-se dizer que a comunicação no distrito se propagou tanto através de meios tecnológicos como grupos de e-mails, redes sociais e blogues, como através de meio tradicional, como o apoio dos agentes de saúde ao transmitirem informações de casa em casa. Além disso, o relacionamento do representante distrital com outros segmentos sociais foi fundamental, levando a imagem do distrito como referência no cenário do movimento de resistência.

Em relação ao aparecimento de lideranças, notou-se que os representantes e as equipes de apoio, oriundas de associações e demais entidades comunitárias, foram destaque em termos de influência de pessoas nas comunidades. Todavia, com a evasão de alguns integrantes do movimento devido ao descrédito no processo, surgiram outras pessoas que até então não se manifestavam em grupo. Embora o principal líder do distrito fosse o representante distrital, outras pessoas com os mais diversificados perfis passaram a influenciar a comunidade. O que chama a atenção é que muitas delas nunca tinham participado de atividades comunitárias e o fomento à liderança concedido pelos organizadores do distrito gerou, portanto, um crescimento pessoal a muitos moradores, com foi mencionado por P11. Os dados revelaram que o poder de liderar não ficou tão restrito ao representante distrital, sendo que na terceira fase várias pessoas que nem sequer tinham experiência em organização participativa em comunidades começaram a influenciar os moradores 
do referido distrito. Assim, depreende-se que há uma descentralização de poder na terceira fasse do processo de elaboração do Plano Diretor de Florianópolis no distrito de Ratones.

Convergindo com isso, o Distrito de Ratones, que em princípio também não tinha uma tradição de participação política, conseguiu, por meio da conscientização de corresponsabilidade, trazer a comunidade para discussões efetivas sobre o plano proposto pela Fundação CEPA.

Tem muita gente que vem para o processo com um monte de ideias, só que querem que os outros executem e elas obtêm [sic] o resultado. Então a ideia é que a gente tenha um processo de corresponsabilidade: deu a ideia, acompanha a execução. Isso fez com que a participação ficasse mais pensada, sem "viagens profundas" e anseios egoístas. (P1)

A participação dos integrantes do distrito e as sugestões proferidas nas falas são aceitas na medida em que há a sua efetiva contribuição para a coletividade. Essa noção de corresponsabilidade acabou sendo reconhecida por muitos outros distritos que tentam implantar a lógica de trabalho; no entanto, nota-se que a ideia precisa de empenho na sensibilização da comunidade, pois, se isso não for bem trabalhado, pode vir a reprimir a participação política das pessoas. Assim, ao conceber que o modelo predominante de organizar visa à segregação entre concepção e execução do trabalho, entende-se que a noção de corresponsabilidade trouxe à tona uma nova faceta de organização que passou a ser adotada não só de forma restritiva no distrito, mas em todo movimento.

No Distrito de Ratones, tenta-se conscientizar as pessoas de que elas estão reunidas em caráter voluntário, para melhorar a vida de todos os que vivem naquela cidade e região. $\mathrm{O}$ pensamento deve ser coletivo e não individualizado. De acordo com P3:

A decisão é coletiva! Essa é lógica que a gente tenta implementar no processo. Não a de ter um decisor e um executor, mas a decisão é coletiva e a responsabilidade também é do coletivo. Então, às vezes chega uma demanda:

- Eu preciso fazer "tal".

- Legal. Podemos aprovar. Então a senhora fica responsável por isso.

- Ah, mas eu não posso.

- Então, sinto muito.

É nessa lógica a gente define a nível de [ sic] planejamento um conjunto de ações que são prioridades, na medida em que surgem outras ações.

A partir da fase de resistência à proposta da CEPA, a tomada de decisão no movimento passou a ser mais autônoma em se tratando de questões diárias, operacionais, e mais coletiva em nível estratégico, o que difere da dinâmica tradicionalmente reconhecida em organizações empresariais, onde as decisões operacionais são tomadas por subordinados e, as estratégicas, pela alta cúpula organizacional.

\section{Conclusão}

As intervenções do movimento na terceira fase do Processo (2009 a 2011) já se tornaram menos passivas e agonísticas (Mouffe, 2000) com o Poder Público. Tornaram-se mais antagônicas, sendo nitidamente estabelecida a fronteira do "nós (do movimento) contra eles (defensores do plano da CEPA)", fase, inclusive, na qual foram adotadas estratégias de risco corporal, onde houve manifestações em público como passeatas, fechamento de ruas e teatralizações, muitas vezes com repressão da Polícia Militar.

Este estudo, ao focar nas práticas organizativas do Distrito de Ratones na fase contrahegemônica do processo de construção do plano diretor participativo de Florianópolis, observou que tais práticas oportunizaram uma resistência, embora não exclusiva, predominantemente antihierárquica, que em certos aspectos se diferem de processos de organizações verticais advindos da lógica empresarial.

No entanto, diante da necessidade de manutenção de recursos de suporte aos encontros no distrito e organização dos eventos, por mais que tenha sido identificada uma mobilização coletiva e um compartilhamento de recursos próprios, há ainda muito presentes resquícios de aspectos consoantes com a teoria de mobilização de recursos, onde se opera com estruturas tradicionais.

Vale, porém ressaltar que, na libra da situação as práticas organizativas, no referido distrito, se voltaram a processos mais abertos e participativos na fase da resistência propriamente dita. 
As pessoas contavam com uma maior flexibilidade e com a parceria dos colegas do distrito para desempenharem suas tarefas. As atividades dependiam do voluntariado; os recursos eram controlados com base em uma política de confiança; as rotinas internas se diversificaram por estarem mais relacionadas com o caráter político do que com o técnico; e não havia mais a obrigatoriedade de elaboração de atas e relatórios.

A comunicação no distrito se propagou de modo eclético, usando tanto os meios tecnológicos quanto os meios tradicionais, o que demonstra um respeito à população e às limitações e peculiaridades locais. O apoio de agentes de saúde foi uma singularidade deste distrito e contribuiu muito para a retomada de participação após os momentos de deslocamento identificados.Dessa forma, pode se afirmar que inicialmente a ideia foi a adoção de meios alternativos àqueles utilizados por segmentos favoráveis à aprovação do Plano Diretor sem participação comunitária; porém como muitos moradores do distrito não tinham acesso a determinados meios de comunicação, optou-se pela utilização de meios de comunicação baseados na lógica dominante de organizar, por meio da disseminação da informação top down por parte do representante distrital e dos agentes de saúde, que seriam de intermediários para os representantes de demais que participavam das reuniões do Núcleo Gestor Municipal Autoconvocado.

Quanto à liderança, apesar do representante distrital ser a grande referência devido à sua experiência, ao seu conhecimento e ao seu relacionamento com os outros segmentos, o que se notou nesta terceira etapa foi que surgiram líderes que nunca tinham participado de atividades comunitárias, fomentados pelos próprios organizadores, o que também se caracteriza como um diferencial perante as práticas hierárquicas da gestão tradicional.

O conceito de corresponsabilidade trouxe à tona uma participação mais madura e consciente não só no âmbito do distrito, mas da cidade. As pessoas começaram a se interessar por discussões referentes ao contexto do Município, a fim de trazerem para dentro do distrito uma nova possibilidade de cidade, outro olhar ao planejamento urbano. A noção de corresponsabilidade perpassa os limites da utopia e conduz a população a pensar também em ferramentas e trajetos a serem seguidos, suas repercussões, vantagens e desvantagens diante das mudanças propostas. Como consequência, a tomada de decisões era coletiva. As decisões operacionais, nem tanto; mas as de maior impacto ao posicionamento do distrito diante da proposta da CEPA, sim. As pessoas tinham coragem de tomar decisões, pois havia o respaldo dos demais. Tudo se discutia em reuniões e, ao surgirem dúvidas, os representantes do distrito as esclareciam no Núcleo Gestor Autoconvocado.

Após o conhecimento das práticas organizativas adotadas pelo Distrito de Ratones na fase de resistência à proposta de plano diretor da CEPA, pôde-se perceber que, embora em alguns momentos tenha havido preocupação com planejamento, objetivos e metas, as atividades são desenvolvidas majoritariamente de forma alternativa ao modelo dominante de organizar e com base no improviso. Nem sempre esse improviso representou uma organização bem consolidada, sendo que, mesmo não tendo sido abordados neste estudo enfaticamente, alguns deslizes e incidentes aconteceram. No entanto, não assumiram papel de destaque neste trabalho por serem coadjuvantes na análise, pois grande parte das categorias do organizar que emergiram do campo consolidou-se de forma efetiva. Uma exceção às práticas alternativas foi o excesso de concentração da responsabilidade ainda assumida pelo representante distrital, que por mais que tenha descentralizado poder er de não seja sua intenção, como se prova pelo empenho em formar novas lideranças, acaba por servir de referência para as lideranças emergentes do distrito no contato com o membros do movimento de modo geral. Além disso, a comunicação não conseguir se sustentar sob os alicerces alternativos de gestão, sendo necessária uma postura mais tradicionalista no repasse de informações.

O caso estudado elucidou as categorias analisadas, e o acesso aos dados e a solidariedade dos membros do distrito foram fatores decisivos para a construção deste artigo.

A Teoria Política do Discurso se mostrou como uma ferramenta de extrema valia para a análise da referida organização, uma vez que os momentos de deslocamento e a constituição da lógica de equivalência no movimento de resistência permitiram conhecer e compreender os processos sociais e a lógica de organização, especificamente no Distrito de Ratones.

O movimento de resistência à proposta de plano diretor de Florianópolis forneceu informações sobre como as organizações que dele faziam parte se articulavam e atuavam através da tentativa de construção de meios alternativos de comunicação, da realização de atividades pautadas na cooperaçãoe na absorção de tarefas de forma voluntária; do fomento às novas lideranças comunitárias; e da participação da comunidade como fundamento para as decisões do movimento. 
Com base no relato de Coelho (2012) vivência neste movimento de 2009 a 2011, na análise das práticas no momento de deslocamento e na constituição da lógica de equivalência, foi possível notar que estas predominantemente rompem com a concepção de organizacional tradicionalista, pautada em um caráter teleológico e reducionista de coordenação racional de atividades. Até meados de 2013, o plano diretor participativo de Florianópolis ainda não tinha sido aprovado, o que confirma a efetividade da resistência. Porém o diálogo com Núcleo Gestor Municipal Oficial foi retomado pelo Prefeito que assumiu seu mandato em 2013 ea percepção de muitos tinham era de que ainda seguia um cunho protocolar, pautado em uma pseudoparticipação. Tal impressão foi ratificada pela aprovação de um plano também divergente dos interesses apontados na Leitura Comunitária (2006-2008) ao "apagar das luzes".

Contudo, pode-se mencionar de forma enfática que o Distrito de Ratones não é mais um distrito sem um passado de luta pela participação política, e que daqui para frente novas práticas contra o modelo dominante de planejar a cidade podem emergir a partir do trabalho desses integrantes de um movimento que, literalmente, fez história no cenário florianopolitano.

Neste trabalho, buscou-se trazer à tona, ao âmbito dos estudos organizacionais, uma reflexão sobre as amarras que as organizações apresentam ao modelo tradicionalmente taken for granted, o qual é muitas vezes subsidiado por um sistema de exploração e exclusão, reduzindo-se à logica produtiva.

A intenção deste estudo não é apenas predizer, mas pensar sobre tal modelo, que se respalda em uma legitimação social e moral da organização racional. Por esse motivo foi interessante este olhar a uma esfera de um movimento social, que nos possibilitou identificar dentre as suas práticas, algumas alternativas ao modelo hegemônico de organizar.

\section{Notas}

1- Aqui, deixamos nosso agradecimento às contribuições criteriosas e cautelosas tecidas a este artigo, por parte dos avaliadores deste periódico.

2- Teatro Álvaro de Carvalho, localizado no Centro de Florianópolis.

3- Fórum da Cidade: grupo de discussões criado a partir da proposta de um líder do movimento popular comunitário no Encontro Experiências em Cena, realizado em 02 de junho de 2001, pelo NESSOP da Universidade Federal de Santa Catarina.

4- COMINTER: Comitê Interuniversitário formado, inicialmente, por professores da UFSC, UDESC, UNISUL e UNIVALI, que se estendeu a outras pessoas da comunidade, com o intuito de discutir a cidade.

\section{Referências}

Alvarez, S, Dagnino, E \& Escobar, A.(2000). O cultural e o político nos movimentos sociais latino americanos. In: Alvarez, S, Dagnino, E. \& Escobar, A. (org.) Cultura e política nos movimentos sociais latino-americanos: novas leituras. Belo Horizonte: EdUFMG.

Alves, J. N. \& Pereira, B, A, D. (2013). Análise das publicações nacionais sobre estudos em relacionamentos interorganizacionais 2004-2009. Revista de Administração e Inovação. 10(20), 169198.

Bardin, L. (2009). Análise de conteúdo. Lisboa, Portugal; Edições 70, LDA.

Barros, M. (2009). El silencio bajo la ultima dictadura militar em La Argentina. Pensamento Plural, Pelotas, 79 (5), 79-101.

BRASIL. Lei no 10.257 de 10 de julho de 2001 . Regulamenta os arts. 182 e 183 da Constituição Federal, estabelece diretrizes gerais da política urbana e dá outras providências. Disponível em: < http://www2.camara.gov.br/legin/fed/lei/2001/lei-10257-10-julho-2001-327901-norma-pl.html>. Acesso em: 10 de outubro de 2013.

BRASIL, Lei no 11.673 de 08 de maio de 2008. Altera a Lei no 10.257, de 10 de julho de 2001 Estatuto da Cidade, para prorrogar o prazo para a elaboração dos planos diretores municipais. Disponível em: <http://www.planalto.gov.br/ccivil_03/_Ato2007-2010/2008/Lei/L11673.htm>. Acesso em: 10 de outubro de 2013.

Cardoso, C. (2001). Análise ambiental do distrito de Ratones. Dissertação de mestrado, Universidade Federal de Santa Catarina, SC, Brasil. 
Castells, M. (1997). A sociedade em rede. Rio de Janeiro, Paz e Terra.

Coelho, K. S. (2012). A resistência à nova proposta de Plano Diretor apresentada pela Prefeitura Municipal de Florianópolis: uma análise das práticas alternativas de organizar. Tese de doutorado, Universidade Federal de Santa Catarina, SC, Brasil.

Coelho, K.S \& Dellagnelo, E.H.L. (2012). O olhar da Revista Brasileira de Ciências Sociais à dimensão organizacional dos movimentos Sociais. Cadernos Gestão Social, Salvador, 3 (1), 69-84.

Coelho, K. S. (2013). Participação e 'Não!' ao Plano da CEPA: uma análise das práticas organizativas de resistência à nova proposta de plano diretor apresentada pelo Poder Público de Florianópolis. Anais do Encontro Nacional da Associação Nacional de Pós-Graduação e Pesquisa em Administração, Rio de Janeiro, RJ, Brasil, 37.

Contu, A. (2002). A political answer to questions of struggle. Ephemera: critical dialogues on organization, 2 (2), 160-174. Disponível: www.ephemeraweb.org

Cooper, R \& Burrell, G. (1988). Modernism, postmodernism and organizational analysis: an introduction. Organization Studies, 9 (1), 91-112.

Cordeiro, A. T\& Mello, S. C. B. de. (2010, setembro) Teoria do Discurso Laclauniana: uma mediação entre teoria crítica e prática política. Anais do Encontro Nacional da Associação Nacional de PósGraduação e Pesquisa em Administração, Rio de Janeiro, RJ, Brasil, 34.

Costa, F.Z.N. et al. (2012). Os Estudos Críticos em Administração, a Political Discourse Theory e a "Ocupação de Wall Street": da Emancipação ao Engajamento Político. Anais do Encontro Nacional de Estudos Organizacionais da Associação Nacional de Pós-Graduação e Pesquisa em Administração, Curitiba, PR, Brasil, 7.

Dellagnelo, E. \& Böhm, S. (2010). Empirical studies and political discourse theory: a critical analysis of resistance from an organizational perspective. Anais do Encontro Nacional de Estudos Organizacionais da Associação Nacional de Pós-Graduação e Pesquisa em Administração, Florianópolis, SC, Brasil, 6.

Frenzel, F., Böhm, S., Quinton P., Spicer A., Sullivan, S. \& Young, Z. (2011). Comparing alternative media in North and South: the cases of IFIWatchnet and Indymedia in Africa. Environment and Planning, 43 (5), $1173-1189$.

Goss, K. P \& Prudêncio, K.(2004). O conceito de movimento sociais revisitado. Em Tese, 2 (1), 75-91.

Griggs, S. \& Howarth, D. (2000). New environmental movements and direct action protest: the campaign against Manchester Airport's second runway. In Howarth, D. R., Norval, A. J. \& Stavrakakis, Y. Discourse theory and political analysis: identities, hegemonies and social change. New York: Manchester University Press.

Howarth, D.\& Stavrakakis, Y. (2000). Introducing discourse theory and political analysis. In Howarth, D. R., Norval, A. J. \& Stavrakakis, Y. Discourse theory and political analysis: identities, hegemonies and social change. New York: Manchester University Press.

Hutton, W.\& Giddens, A. (2004). No limite da racionalidade: convivendo com o capitalismo global. Trad. Maria Beatriz de Medina. Rio de Janeiro: Record.

Laclau, E. (1986). Os novos movimentos sociais e a pluralidade do social. Revista Brasileira de Ciências Sociais, 1 (2), 41-47.

Laclau, E. (1990). New reflections on the revolution of our time. New York: Verso.

Laclau, E. (2011). Emancipação e diferença. Rio de Janeiro: EdUERJ.

Laclau, E. \& Mouffe, C. (1985) Hegemony and socialist strategy: towards a radical democratic politics. London: Verso.

Melucci, A. (1996). Challenging codes: collective action in the information age. Cambridge: Cambridge University Press.

Mendonça, D. (2003). A Teoria do discurso de Laclau e Mouffe: em direção à noção de significante vazio. Barbarói, 18, 55-71.

Misoczky, M. C. A. (2012). Rememorando a Organização e Práxis dos Centros Populares de Cultura. Anais do Encontro Nacional de Estudos Organizacionais da Associação Nacional de Pós-Graduação e Pesquisa em Administração, Curitiba, PR, Brasil, 7. 
Misoczky, M.C. A, Flores, R.K \& Böhm, S.(2008). A práxis da resistência e a hegemonia da organização. Organizações e sociedade, 15 (45).

Mouffe, C. (2000). The democratic paradox. New York: Verso.

Nascimento, O. (2008). Ratones. Disponível:

<http://amoratones.blogspot.com.br/2008/08/ratones.html>

Otto, B \& Böhm, S. (2006). The people and resitance against international business, the case of the Bolivian "water war". Critical Perspectives on International Business, 2 (4), 22-39.

Paes de Paula, A. P. (2002). Tragtenberg revisitado: as inexoráveis harmonias administrativas e a burocracia flexível. Revista de Administração Pública, 36 (1), 127-144.

Administração pública brasileira entre o gerencialismo e a gestão Social. Revista de Administração de Empresas, 45 (1), 36-49.

Popper, K. (1975). A lógica da pesquisa científica. Trad. Leonidas Hegenberg e Octanny da Mota. São Paulo: Cultrix/EDUSP.

Santos, O. A. (2007). Cidade, Cidadania e Planejamento Urbano: desafios na perspectiva da reforma urban. In: Feldman, S \& Fernandes, A. (org) O Urbano e o regional no Brasil contemporâneo: mutações, tensões, desafios. Salvador: EDUFBA, 293-314.

Scherer-Warren, I \& Lüchmann, L.H.H. (2004). Situando o debate sobre movimentos sociais e sociedade civil no Brasil: introdução. Política \& Sociedade, Florianópolis, 5, 13-35. Semestral.

Solé, A. (2004). ¿Qué es una empresa ? Construcción de un idealtipo transdisciplinario. Working Paper, Paris.

Spicer, A. \& Böhm, S.(2007). Moving management: theorizing struggles against the hegemony of management. Organization Studies. 28, 1667-1698.

Spicer, A. \& van Bommel (2011). Hail the Snail: Hegemonic Struggles in the Slow Food Movement. Organization Studies. 32 (12), 1716-1744.

Taylor, N. (2014) Theorising capitalist diversity: The uneven and combined development of labour forms. Capital \& Class.38 (1), 129-141.

Telles, V. S.(1987). Movimentos sociais: reflexões sobre a experiência dos anos 70. In: SchererWarren, I., Krischke, P. J. (Org.). Uma revolução no cotidiano?: os novos movimentos sociais na América Latina. São Paulo: Brasiliense.

Touraine, A.(1977). Movimentos sociais e ideologias nas sociedades dependentes. In: Albuquerque, J.A.G. (org.) Classes médias e política no Brasil. Rio de Janeiro: Terra e Paz. 